\title{
An assessment on employees' business intelligence and CRM on customer satisfaction: A case study of Auto industry
}

\author{
Somayeh Rezaei and Ali Alikhani*
}

Department of Management and Accounting, North Tehran Branch, Islamic Azad University, Tehran, Iran

\section{H R O N I C L E}

Article history:

Received June 28, 2013

Received in revised format

19 October 2013

Accepted 20 December 2013

Available online

December 262013

\section{Keywords:}

Customer satisfaction

Business intelligence

CRM \begin{abstract}
A B S T R A C T
This paper performs an empirical investigation on employees' business intelligence and customer relationship management and their effects on customer satisfaction. The proposed study has been implemented among 625 people, 240 sales representative and 385 regular customers, who are involved with products of an Iranian automaker named Iran Khodro. The proposed study designs three questionnaires in Likert scale for business intelligence, customer relationship management and customer satisfaction and Cronbach alpha have been calculated for these three questionnaires as $0.85,0.84$ and 0.78 , respectively. The study distributes the questionnaires among groups, employees as well as customers, and using one-way t-student test as well as regression technique the study finds that business intelligence and customer relationship management are within an acceptable limit $(\mathrm{P}<0.01)$ and they positively influence on customers' satisfaction $(\mathrm{P}<0.01)$.
\end{abstract}

C 2014 Growing Science Ltd. All rights reserved.

\section{Introduction}

Business intelligence plays essential role on the success of organizations and building a sustainable growth on business development (Negash, 2004; Gangadharan \& Swami, 2004; Ranjan, 2009; Vitt et al., 2010; Loshin, 2012). The recent advances on information technology (IT) have also boosted business intelligence adaptation in organizations. Chung et al. (2005), for instance, presented a visual framework for knowledge discovery on the Web by applying an empirical investigation of business intelligence exploration. According to Tarokh and Ghahremanloo (2007), World Wide Web has become an essential channel for building the businesses and IT provides the opportunity to reach the global market for the Enterprises. IT adaptation has become the first point of contact and the customers for the businesses. This helps us understand customer's behavior by analyzing and profiling their behavior. Data warehousing as well as data mining technologies and contact technology may also facilitate the e-businesses to better understand their e-customers. 
Customer Relationship Management (CRM) is one of most popular methods for achieving this goal (Anderson-Lehman et al., 2004; Sin et al., 2005; Lawton, 2006). Tarokh and Ghahremanloo (2007) performed an investigation on customer intelligence, collaborative CRM, presented a model in contact centers and channels and investigated the model in an Iranian automaker. Hall (2004) investigated the missing point between business intelligence and CRM adaptation. Mithas et al. (2005) evaluated the impact of CRM on customer knowledge and customer satisfaction. An investigation of archival data for a cross-section of U.S. firms indicated that the implementation of CRM applications was positively associated with improved customer knowledge and improved customer satisfaction. They also showed that gains in customer knowledge were enhanced when firms share their customer-related information with their supply chain partners.

Hallowell (1996) performed an investigation on the relationships among customer satisfaction, customer loyalty, and profitability. They reported that when customers are satisfied with their services, they will more likely to purchase product. Verhoef (2003) performed an empirical study to understand the impact of CRM efforts on customer retention and customer share development. They reported that affective commitment and loyalty programs that provide economic incentives positively influences both customer retention and customer share development, whereas direct mailings affect customer share development. However, the impact of these variables was rather small. They also reported that firms could apply the same strategies to influence both customer retention and customer share development.

\section{The proposed study}

This paper performs an empirical investigation on employees' business intelligence and customer relationship management and their effects on customer satisfaction. The proposed study has been implemented among 625 people, 240 sales representative and 385 regular customers, who are involved with products of an Iranian automaker named Iran Khodro. The proposed study designs three questionnaires in Likert scale for business intelligence, customer relationship management and customer satisfaction and Cronbach alpha have been calculated for these three questionnaires as 0.85 , 0.84 and 0.78 , respectively. These results are within the desirable limit and we therefore analyze the results. The proposed study considers the following hypotheses,

1. Employees' business intelligence is in desirable level in Iran Khodro automaker.

2. CRM is in desirable level in Iran Khodro automaker.

3. Business intelligence and CRM positively influence customer satisfaction in Iran Khodro automaker.

The study distributes the questionnaires among groups, employees as well as customers, and using one-way t-student test as well as regression technique analyzes the results as follows,

Customer satisfaction $=\beta_{1}$ Business intelligence $+\varepsilon$,

Customer satisfaction $=\beta_{2} \mathrm{CRM}+\varepsilon$,

where $\beta_{1}$ and $\beta_{2}$ are coefficients to be estimated and $\epsilon$ is the residual of the regression models.

\section{The results}

In this section, we present details of our findings on testing various hypotheses and the survey. Table 1 demonstrates the results of the implementation one-way t-student test. 
Table 1

The results of t-student test

\begin{tabular}{cccccc}
\hline Variable & Mean & Standard deviation & df. & t & Sig. \\
\hline Business intelligence & 3.24 & 0.57 & 239 & 6.438 & 0.00 \\
CRM & 3.39 & 0.69 & 384 & 11.112 & 0.00 \\
\hline
\end{tabular}

As we can observe from the results of Table 1, the mean of business intelligence and CRM are 3.24 and 3.39 and they are well above the measurement index of 3. These two items are statistically meaningful when the level of significance is one percent. Table 2 shows details of our findings on the implementation of regression analysis.

Table 2

The summary of regression analysis

\begin{tabular}{lcccc}
\hline Variable & Adjusted R-Square & Beta & F & P \\
\hline Business intelligence & 0.25 & 0.51 & 82.975 & 0.00 \\
CRM & 0.44 & 0.66 & 303.447 & 0.00 \\
\hline
\end{tabular}

The results of Table 2 clearly indicate that business intelligence and CRM influence on customer satisfaction, positively when the level of significance is one percent. Adjusted R-Square values for Eq. (1) and Eq. (2) are 0.25 and 0.44 , respectively. These results indicate that customer satisfaction is influenced by CRM more than business intelligence is. In other words, CRM could increase customer satisfaction more than business intelligence. These results confirm three hypotheses of the survey.

\section{Conclusion}

In this paper, we have presented an empirical investigation to study the effects of business intelligence and customer relationship management on customer satisfaction in one of Iranian automakers. The proposed study has used three questionnaires in Likert scale and using t-student and regression techniques, we have concluded that CRM plays essential role on customer satisfaction and business intelligence influences customer satisfaction, positively.

\section{Acknowledgement}

The authors would like to thank the anonymous referees for their comments on earlier version of this paper.

\section{References}

Anderson-Lehman, R., Watson, H. J., Wixom, B. H., \& Hoffer, J. A. (2004). Continental Airlines flies high with real-time business intelligence. MIS Quarterly Executive, 3(4), 163-176.

Chung, W., Chen, H., \& Nunamaker Jr, J. F. (2005). A visual framework for knowledge discovery on the Web: An empirical study of business intelligence exploration. Journal of Management Information Systems, 21(4), 57-84.

Gangadharan, G. R., \& Swami, S. N. (2004, June). Business intelligence systems: design and implementation strategies. In Information Technology Interfaces, 2004. 26th International Conference on (pp. 139-144). IEEE.

Hall, J. (2004). Business intelligence: The missing link in your CRM strategy. DM REVIEW, 14, 3640.

Hallowell, R. (1996). The relationships of customer satisfaction, customer loyalty, and profitability: an empirical study. International Journal of Service Industry Management, 7(4), 27-42.

Lawton, G. (2006). Making business intelligence more useful. Computer, 39(9), 14-16. 
Loshin, D. (2012). Business intelligence. Access Online via Elsevier.

Mithas, S., Krishnan, M. S., \& Fornell, C. (2005). Why do customer relationship management applications affect customer satisfaction?. 69(4), Journal of Marketing, 201-209.

Negash, S. (2004). Business intelligence. Communications of the Association for Information Systems, 13(1), 177-195.

Ranjan, J. (2009). Business intelligence: concepts, components, techniques and benefits. Journal of Theoretical and Applied Information Technology, 9(1), 60-70.

Sin, L. Y., Alan, C. B., \& Yim, F. H. (2005). CRM: conceptualization and scale development. European Journal of Marketing, 39(11/12), 1264-1290.

Tarokh, M. J., \& Ghahremanloo, H. (2007, August). Intelligence CRM: a contact center model. In Service Operations and Logistics, and Informatics, 2007. SOLI 2007. IEEE International Conference on (pp. 1-6). IEEE.

Verhoef, P. C. (2003). Understanding the effect of customer relationship management efforts on customer retention and customer share development. Journal of Marketing, 67(4), 30-45.

Vitt, E., Luckevich, M., \& Misner, S. (2010). Business intelligence. O'Reilly. 